\title{
p分布荷重による累積疲学被害 (第二啹)
}

\begin{abstract}
一低・高サイクル寿命域疲労に対する改良モデル—
正員 飯 田國 廣* 正員 洪 性 祚**

Cumulative Fatigue Damage by Block Loading with $p$-Distribution (2 nd Report)

-A Revised Model Applicable to Stromeyer's Expression-_

by Kunihiro Iida, Member Sungjo Hong, Member

Summary

In view of non-conservative prediction of cumulative fatigue life calculated by Miner's and Haibach's methods, the authors proposed in a previous paper a new model providing better and conservative prediction, although it was limited in application to only the bi-linear fatigue diagram in high cycle fatigue regime. If a fatigue diagram will be required to be expressed for a wide range of fatigue life from very low cycle to high cycle regimes, it is a convenient way to express the diagram by Stromeyer's expression.

The previously proposed model is developed in the present paper so as to be applicable to Stromeyer's as well as bi-linear expressions of a basic fatigue diagram in undamaged condition. The newly proposed model in this paper is based on a concept consisting of two assumptions; (i) Fatigue damage will be accumulated as a power function of cycle ratio, and (ii) Fatigue strength at infinite fatigue life or at $10^{7}$ cycles will decrease functionally according as accumulation of fatigue damage.
\end{abstract}

\section{記}

号

$p$ : 応力振幅皇なは歪振幅の頻度分布係数

$S_{a i}$ : 任意の $i$ レベルに打ける応力振幅 (MPa)

$\varepsilon_{a i}:$ 任意の $i$ レベルに打訬る歪振幅

$\bar{S}_{a}: 1$ ブロック中の応力振幅の最高值 $(\mathrm{MPa})$

$\bar{\varepsilon}_{a}: 1$ ブロック中の歪振幅の最高值

$\varepsilon_{e 0}$ : 非損傷材に対する Stromeyer 式中の仮想疲労

限

$\varepsilon_{e D}$ : 損傷材汇対する Stromeyer 式中の仮想疲労限, 必要なときは $D$ の数值を括弧に入れて示す, $\varepsilon_{e D}(D)$

$\varepsilon_{a}^{*}$ : 歪振幅遷移值, 繰返し硬化も繰返し軟化も生じ ないような歪振幅の值

$N$ : 疲学寿命

$N_{j}$ : 第 $j$ ステップでの歪振幅 $\varepsilon_{a j}$ または応力振幅 $S_{a j}$ による疲労寿命 $\left(N_{c j}\right.$ または $\left.N_{f j}\right)$

$N_{c}$ : 龟裂発生寿命

$N_{f}$ : 試験片の破断寿命, 上限荷重が定常状態の75\% に低下寸るまでの寿命で定義した。

* 東京大学工学部船舶工学科

** 東京大学大学院工学系研究科

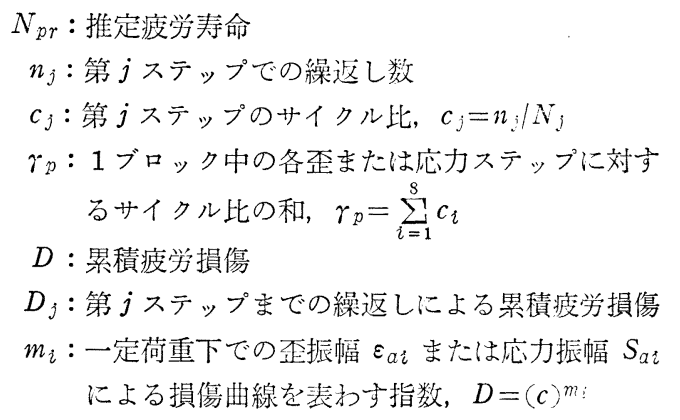

\section{1 まえがき}

ランダム荷重が加わる構造要素の瘦労強度を評価する ために，ランダム荷重の性状に応じたブロック荷重を加 壳て試駩する方法があるが，この際問題とされるのは代 替となるブロック荷重に拈ける各ステップの応力振幅の 大きさとこれを加光る回数の組合せ，すなわらブロック 形状である。1970 年頁西独の Haibach は各種棈造物に ついて実測したランダム荷重を分析してい和ゆるっ分布 ブロック形状を提案し，㑇せて実測したランダム荷重お よびр分布ブロック荷重による疲労試験を実施し, 両者 の間に良好な相関性を与兄る累積疲労被害評洒法を提示 した1)。その後特に欧州においては，新種の鋼材や溶接 
法による各種溶接継手に関し， pをパラメータとする 分布ブロック荷重試験が広く実施され，またp分布の考 え方は構造部材の疲労荷重負担率の分類に有用であると の見解から西独のクレーン構造規格 (DIN 15018) にも 採用されている。

一方, 著者ら 2),3) はこれまで SM $41 \mathrm{~A}$ 鋼拉よび SM $50 \mathrm{~B}$ 鋼を供試材と与る两振り曲げ高サイクル疲労によ りр妾パラータとするp分布ブロック荷重疲労試験を 実施し, 累積疲学を受けた場合の疲労表命予測に関して, Miner, Haibach,ならびに修正 Miner の方法いずれも が必ずしも安全側の予測寿命を与光ないことを明らかに するとともに，定全側の予測寿命を与えるようなより良 好な累積疲労被害モデルを提案し，かつ修正を行ってき た。

さて, 以上述べたことはすべて瘦労寿命が $10^{5}$ サイク ル以上の苚サイクル疲学関することである。しかし， すでこ 14 年学经た ASME の B \& PV Code Sec. III や, 定的られてからほ济 10 年を経過し, そして現在海洋 溝造物の疲労設㖕線図として良く用いられている AWS の溶接搆造规格 Sec. 10 に含立れている疲労設計線図 ぶ，前者においては 10 から $10^{6}$ の，また後者において は $10^{2}$ から $10^{7}$ の疲労寿命域にわたって与えられてい ることから自明のように, 今や構造要素の疲労設計線図 は単に低サイクル瘦労域, 岗るい弾に高サイクル疲労 域に封して与えられるべきものではなく，低サイクル域 から高サイクル域に及ぶ広範国の寿命域にわたって連続 して与兄ら礼るべきものとなっている。てしてこのよう な疲労線図は呧サイクル域では歪制御疲労データに, ま た高サイクル域では荷重制御度労データに基づいてい ๖。

一方, 諸種の度労祋計規格では, 例外なく景積疲労被 害の評洒は Miner の方法によっているが，著者らのを 含め多数の㼋究によって Miner 法が非安全側の予測寿 命を与える場合の多いことが明らかになっている以上, これて代りしか子低・高サイクル全域にわたって良好か

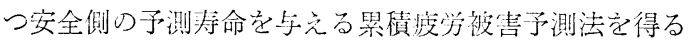
ことは重要なテーマで市らう。

著者が研究を分担した日本溶接協会のFRC 委員会 (軽水炬権造の疫労強度研究) により，原子炣構造鋼材 であるSFVV 3 铜を供試材として低・高サイクル域に 岕ける 分布歪制御ブロック形状の累積瘦学被害の試験 が $4 \times 10^{2}$ 〜 $10^{6}$ サイクルにわたって行われたが，ての報 告書は時間の制約上データの記述を主眼とし, 深い考察 は行われて扔らず, 一般性の丙る累積渡労被害予測法の 検討はなされなかった。そこで著者はFRC 委員会が出 したデータを再悗討し，かつ前報3)で提案した方法を発 展させて，低・淌サイクル疲学待命域全籁困汇わたって
適用可能なモデルを考え，これを FRC 委員会のデータ ならびに前報2),3)のデータに適用してモデルの妥当性を 確かめた。

\section{2 累積疲学被害評価モデルの提案}

\section{$2.1 \boldsymbol{p}$ 分布ブロック形状の相違による寿命の変化}

一般に疲労寿命が 2 桁ないし 3 桁にわたる疲労強度線 図は両対数表示で直線, すなわら指数表示されることが 多いが, 歪制御疲労で得られる 10〜 $10^{4}$ サイクル寿命で のデータならびに荷重制御疲労で得られる $10^{4} \sim 10^{7} サ$ イクル寿命でのデータを包含して，10〜107 サイクルに わたる疲労強度と寿命との関係を数式表示する際には, Stromeyer が高サイクル疲労強度線図の表示式として 1914年に提案した式の応力項を歪に置き換えた次式が広 く用いられる。

$$
\varepsilon_{a}=A \cdot N^{-K}+\varepsilon_{e 0}
$$

寸なわら原式の $S_{e 0}$ (無限サイクル寿命での疲労限) の 代りに $S_{e 0} / E$ と見なされる定数 $\varepsilon_{e 0}$ を，また低サイク ル疲労域にあっては公称応力振幅 $S_{a}$ の代りに歪制御痩 労にお活る制御値である歪振幅 $\varepsilon_{a}$, ならびに高サイク ル疲労域にあっては $S_{a} / E$ としての $\varepsilon_{a}$ を代入した式で 岁るが, 以下本論文では (1) 式の形式の表示式, ある いは $N$ を陽関数とした式を Stromeyer 式と呼ぶ。

単に高サイクル疲労域のみならず歪制御低サイクル疲 労域での疲労も含む累積疲労に関する累積疲労被害モデ ルないしはこのような累積疲労を受ける材料の寿命予 测は無被害材に対する Stromeyer 式を基本とすること こする。

さて $\mathrm{Haibach}^{1)}$ が提案した $p$ 分布ブロック形状と $p$ を パラメータとしたときの $\varepsilon-N($ または $S-N$ ) 線図を Fig. 1 に例示する。狭寿命域での荷重制御による 2 直線 近似の $S-N$ 基本線図の場合は破線で示してある。 $\bar{\varepsilon}_{a}$ (狭寿命域荷重制御では $\bar{S}_{a}$ ) は8ステップから成る任意 のブロック中での歪（または応力）振幅の最大值であり 図では第 1 ステップでの振幅值である。1から 8 までの ステップの歪 (または応力) 振幅は $\varepsilon_{a \imath}$ (または $S_{a \ell}$ ) と表示する。左図に打いて $p=0$ の曲線は正規分布に従 う振幅の頻度分布であり，これを $\varepsilon_{a i}$ (または $S_{a \imath}$ ) × $n_{i}$ 回のステップ 8 つ置き換える。この際 $S_{a \imath}$ と $n_{\imath}$ の組 合せ方は一定の法則1 ${ }^{13}$ 則に従う。 $p=0.5$ は $p=0$ の ブロック形状の変形であり, $p=1$ は定振幅疲労を意味 する。横軸は累積繰返し数 $\sum_{i} n_{i}$ の対数で, 同図の場合 は $1 \times 10^{6}$ を 1 ブロックの累積繰返し数としている。例 党ば, $p=0.5, \bar{\varepsilon}_{a 1}$ のブロックを $g$ 回繰返し, さらに $g$ +1 回目のブロックにおいてステップ 1 で $n_{1}$ 回, ステ ップ 2 で $n_{2}$ 回，それにステップ 3 で半端な繰返し数 $r_{3}$ 回で肉眼亀裂発生または破断したとすれば，このときの 


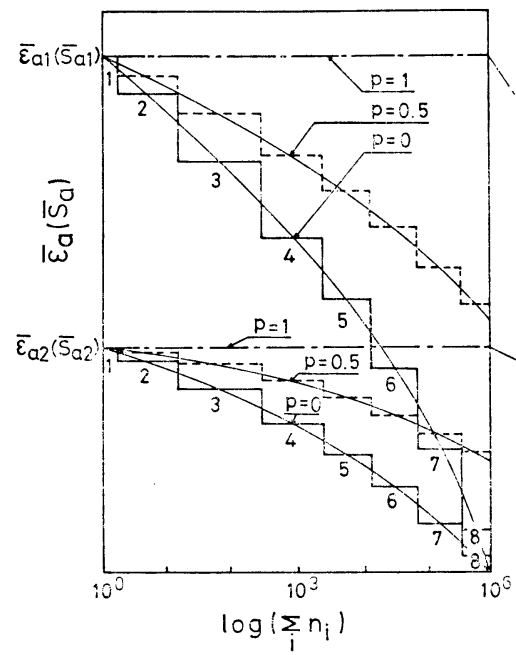

(a)

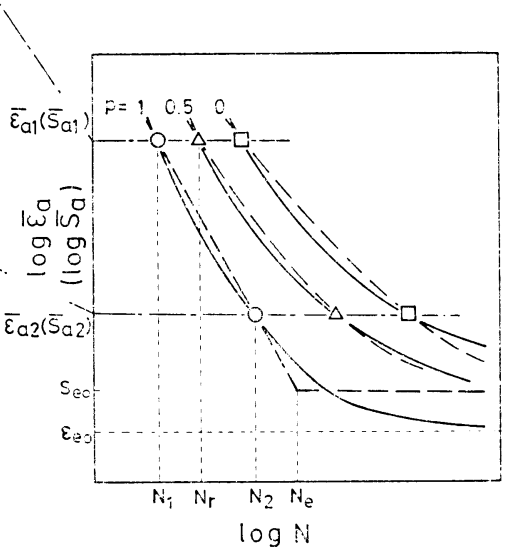

(b)

Fig. 1 Examples of $p$-distribution block shape and fatigue strength curves as a function of parameter $p$

寿命 (累積繰返し数) は $g \times 10^{6}+n_{1}+n_{2}+r_{3} \equiv N_{r}$ とな る。同一の $\sum_{i} n_{i}$ では $p=1$ に比べて $p=0.5$ の方が疲 労被害が少ないから $N_{r}$ は当然 $N_{1}$ より長くなる。この $N_{r}$ を $p=1$ に対する疲学強度線図から精度良く予測す ることが本論文の命題である。

\section{2 疲労損傷進行過程の評価}

前報 ${ }^{3)}$ 之同様に, $\varepsilon_{a i}$ の定振幅疲労による疲労損䅞 $D_{i}$ は $\varepsilon_{a \imath}$ でのサイクル比 $c_{i}$ の $m$ 乗則で進行すると仮定

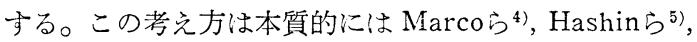
Manson ら ${ }^{6)}$ が仮定しな概念之同様で市る。すなわち

$$
D_{i}=\left(c_{i}\right)^{m_{i}}
$$

いま，一定振幅 $\varepsilon_{a i}\left(\right.$ または $S_{a i}$ )の負荷による損慯が 進行して肉眼亀裂発生寿命 $N_{c}$ あるいは破断寿命 $N_{f}$ に 至る場合, 指数 $m$ を次のような関数と考学る。

$$
m=f\left(\varepsilon_{a i} \text { または } S_{a i}, M, H, \mathrm{EV}, \mathrm{NE}\right)
$$

ここに $M:$ 材料固有の定数, $H:$ 繰返し速度, $\mathrm{EV}:$ 環 境効果, $\mathrm{NE}$ : 切欠効果である。材料が同一で, 繰返し 速度の影響が無視し得る範囲内, 同一環境中, 切欠の形 状俰数が同一といら条件の下で定歪振幅もしくは定応力 振幅疲労試験を行ったとすると $m$ は $\varepsilon_{a \imath}$ (または $S_{a \ell}$ ) のみの関数となる。Marco ら ${ }^{4)}$ は高サイクル疲労に関し て同様な概念を提唱し, 応力振幅 $S_{a}$ と指数 $m$ との関俰 は， $S_{\alpha_{1}}>S_{a_{2}}$ のとき $m_{1}<m_{2}$ であるべきであるとし，

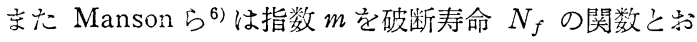
き $N_{f 2}>N_{f 1}$ のとき $m_{1}<m_{2}$ であるとした。さらに Hashin $^{5)}$ む同様な指数型の損傷則を提案しており，そ の指数 $m$ を $S_{\alpha} / S_{0}$ または $N / N_{e}$ の関数とおいている。 なお，ここに $S_{0}$ は引張強さに近い值，一方， $N_{e}$ は Fig. 1(b) に示す寿命である。そこで，本諭文において

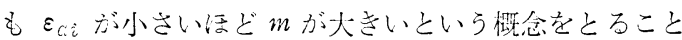
にする。従来の 2 段 2 重高サイクル疲労試験を报った多 くの論文により, 応力振幅を高から低に下げる Hi-Lo の場合にはサイクル比の和が 1 より小さくなり, 逆に Lo-Hi の場合にはサイクル比の和が 1 より大といら事 実もあるが，この挙動は上述の概念，すなわち $S_{a}$ ボ小 さくなるに従って（2）式の $m$ が大きくなるといら概念 から容易に説明できる。

さて, 歪制御疲労では歪振幅の大小によって真応力振 幅が增加台るいは減少するいかゆる繰返し硬化・軟化現 象が生ずることは良く知られているし，また荷重制御疲 労ではこの逆に歪振幅が変化する。换言すればいずれの 場合も振幅值の大小により繰返しに伴ってヒステリシス エネルギーぶ変化する。そこでヒステリシスエネルギー もまた疲労損傷の蓄積に対して何らかの寄与をすると考 兄るのが妥当であらう。この考光方に立ち, 正制御瘦労 では，前報》で明らかにした遷移丕振幅 $\varepsilon_{a}^{*}$ (繰返し便 化も乾化も示さない需振幅)，一方，荷重制御疲労では 制御值が公称応力であることを考慮して $\varepsilon_{a}^{*}$ に対する公 称応力 $S_{a l}^{*}$ 基準値之考克, $m$ 次次式のように $\varepsilon_{a}^{*} / \varepsilon_{a l}$ あるいは $S_{a}^{*} / S_{a i}$ を变数とする関数と沶いた。

$$
\left.\begin{array}{l}
m_{i}=g\left(\varepsilon_{a}^{*} / \varepsilon_{a i}\right)[\text { 歪制御], } \\
m_{i}=h\left(S_{a}^{*} / S_{a i}\right)[\text { 荷重制御] }
\end{array}\right\}
$$

(4)式の $\varepsilon_{a}^{*}$ ならびに $S_{a}^{*}$ を求めるためには材料の静的 㧍よび繰返し応力一丕関保つまり，繰返し硬化，軟化特 性がわかっていな胡ればならない。そして，このため には数本の静的引張試験ならびに疲労試験を行わなけれ ばならないが，一方 $S_{a}^{*}$ の值を静的ならびに繰返し応 力-歪関倸が得ら礼ている 8 種類の鋼材（引張強さ $=437$ 
〜794 MPa）について調べたところ， $S_{a}^{*}$ と材料の降伏 応力 $S_{i}$ との間に和打よそ次の上らな関倸を見出した。

$$
S_{a}^{*} \fallingdotseq 1.05 S_{y}
$$

(5) 式の係数は 1 亿近いので，実用的には $S_{a}^{*}$ を $S_{y}$

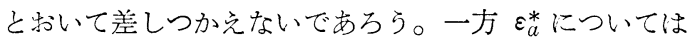
材料の引張強さ $S_{u}(\mathrm{MPa})$ との間に次式のような関係? が尊かれているから, 歪制御データがない場合は引張強 さ $S_{u}(\mathrm{MPa})$ から近似的汇 $\varepsilon_{a}^{*}$ 求め得る。

$$
\log \varepsilon_{a}^{*}=0.00487 \cdot S_{u}-4.544
$$

次阔題となるのは (4) 式の関数形である。ヒステ リシスループエネルギーの繰返し特性を扱った前報》の データを再検討したところ繰返し硬化市るいは軟化によ るループエネルギーの変化量は大略 $\varepsilon_{a}^{*} / \varepsilon_{a i}$ の 0.3 乗 則に従っていることを見出した。またデータ数が少なく 定説的にい光ないが，一応本論文では仮説的に $m_{i}$ を $\varepsilon_{a}^{*} / \varepsilon_{a i}$ の 0.3 乘と打くことにし, 荷重制御についても これにならうことにした。すなわち上述の簡単化を含め て $m_{i}$ は次式となる。

$$
m_{i}=\left(\varepsilon_{a}^{*} / \varepsilon_{a \imath}\right)^{0.3} \text { または } m_{i}=\left(S_{y} / S_{\alpha \imath}\right)^{0.3}
$$

さて，これまで議論してきたことは，一定歪振幅宗た は一定応力振幅の下での疲労損傷の進行に対する評価で あったが, もっと一般的な場合，すなわち変動振幅下で の疲労過程について考光ることにする。例えば4段の歪 振幅によって $N_{c}$ または $N_{f}$ に至った場合の損傷の進 行について Fig. 2 に例示する。まず第 1 ステップの歪振 幅 $\varepsilon_{a 1}$ でサイクル比 $c_{1}$ だけ負荷したとすると，損傷は a 点から始まり $\varepsilon_{a_{1}}$ に対する損傷曲線 ( $(2)$ 式の指数 は $\left.m_{1}\right)$ 上の $c_{1}$ に対応する点 $\mathrm{b}$ まで進行し， $D_{1}$ だけ 損傷が蓄積される。なお $D_{1}$ は次式で計算される。

$$
D_{1}=\left(c_{1}\right)^{m_{1}}
$$

次に，第 2 ステップの歪振幅 $\varepsilon_{a 2}$ でサイクル比 $c_{2}$ を負

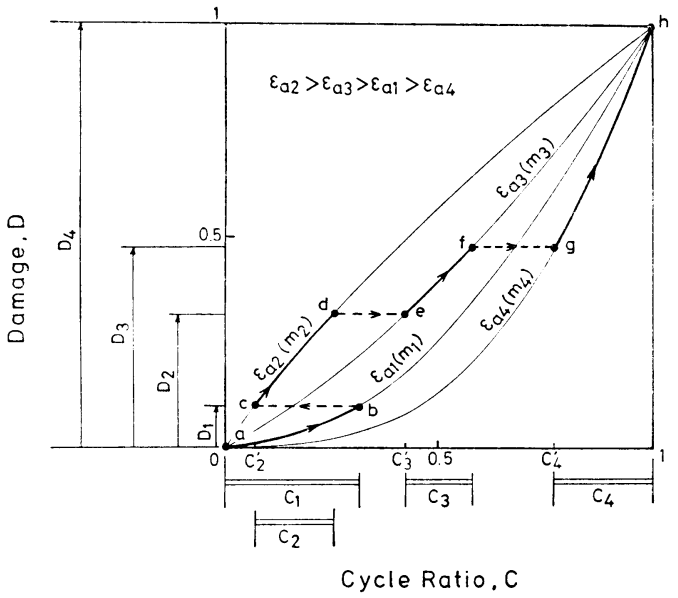

Fig. 2 Accumulation process of fatigue damage due to cycle ratio
荷すると，それまで $D_{1}$ という損傷が蓄積されているの で, $\varepsilon_{a 2}$ による損傷は同歪振幅に対する損傷曲線上の $D_{1}$ に対応する $\mathrm{c}$ 点から始まり $c_{2}$ だけサイクル比が増加し た点 $\mathrm{d}$ に至る。そして第 2 ステップまでの累積損傷 $D_{2}$ は同図から次のように計算される。

$$
D_{2}=\left(c_{2}{ }^{\prime}+c_{2}\right)^{m_{2}}
$$

ここに, $c_{2}{ }^{\prime}$ は点 $\mathrm{c}$ に対する横軸上の座標値。また,

$$
\begin{gathered}
\left(c_{2}{ }^{\prime}\right)^{m_{2}}=D_{1}, \quad c_{2}{ }^{\prime}=\left(D_{1}\right)^{1 / m_{2}}=\left(c_{1}\right)^{m_{1} / m_{2}} \\
\therefore \quad D_{2}=\left(\left(c_{1}\right)^{m_{1} / m_{2}}+c_{2}\right)^{m_{2}}
\end{gathered}
$$

さらに, 第 3 ステップの歪振幅 $\varepsilon_{a 3}$ でサイクル比 $c_{3}$ を 負荷したとすれば，第 2 ステップにおける取扱いと同様 に $\varepsilon_{a 3}$ による損傷は歪振幅 $\varepsilon_{a 3}$ に対する損傷曲線上の $\mathrm{e}$ 点から始まり $\mathrm{f}$ 点に至る。第 3 ステップまでの累積損 傷 $D_{3}$ は (9), (10) 式と同様にして

$$
\begin{gathered}
D_{3}=\left(c_{3}{ }^{\prime}+c_{3}\right)^{m_{3}} \\
\therefore \quad D_{3}=\left(\left(\left(c_{1}\right)^{m_{1} / m_{2}}+c_{2}\right)^{m_{2} / m_{3}}+c_{3}\right)^{m_{3}}
\end{gathered}
$$

で与えられる。最後に第 4 ステップの歪振幅 $\varepsilon_{a 4}$ でサイ クル比 $c_{4}$ を負荷した後に疲労破壊したとすると,

$$
D_{4}=1
$$

また，第 4 ステップで疲労破壊するに至らなかった場合 の累積損傷 $D_{4}$ は (10)，(12）式を導いたようにして

$$
D_{4}=\left(\left(\left(\left(c_{1}\right)^{m_{1} / m_{2}}+c_{2}\right)^{m_{2} / m_{3}}+c_{3}\right)^{m_{3} / m_{4}}+c_{4}\right)^{m_{4}}
$$

で与兄られるなおお第 4 ステップの途中で疲労破壊した 場合, 疲労破壊に要する第 4 ステップのサイクル比 $c_{4 r}$ は次式で与兄られる。

$$
c_{4 r}=1-c_{4}^{\prime}=1-\left(\left(\left(c_{1}\right)^{m_{1} / m_{2}}+c_{2}\right)^{m_{2} / m_{3}}+c_{3}\right)^{m_{3} / m_{4}}
$$

(14)，(15）式を一般表示すると, 第 $j$ ステップまでの累 積損傷 $D_{j}$ は

$$
\begin{gathered}
D_{j}=\left(c_{j}{ }^{\prime}+c_{j}\right)^{m_{j}} \\
\therefore \quad D_{j}=\left(\left(\cdots \cdots\left(\left(c_{1}\right)^{m_{1} / m_{2}}+c_{2}\right)^{m_{2} / m_{3}}\right.\right. \\
\left.\left.+\cdots \cdots \cdot c_{j-1}\right)^{m_{j-1} / m_{j}}+c_{j}\right)^{m_{j}}
\end{gathered}
$$

また，第 $j$ ステップで疲労破壊した際の残存サイクル比 $c_{j r}$ は,

$c_{j r}=1-\left(\cdots \cdots \cdot\left(\left(c_{1}\right)^{m_{1} / m_{2}}+c_{2}\right)^{m_{2} / m_{3}}+\cdots \cdots \cdot c_{j-1}\right)^{m_{j-1} / m_{j}}$

で与兄られ，残存サイクル数 $n_{j r}$ は

$$
n_{j r}=c_{j r} \cdot N_{j}
$$

である。したがって疲労破壊は

$$
D_{j}=1
$$

で生じ, 疲労破壊に至る繰返し数の総和, つまり疲労寿 命の予測值, $N_{p r}$ は各ステップの繰返し数を $n_{i}(i=1$ 〜j) とすると

$$
N_{p r}=\sum_{i=1}^{j-1} n_{i}+n_{j r}
$$

と算出される。第 $j$ ステップまでの累積損傷量を与える 
（16）式は, 第 $j$ ステップでのサイクル比 cjに，j-1 ステップまでの累積サイク ル比ならびに荷重負荷順序を考慮に入れた $c_{j}{ }^{\prime}$ を加光た変換サイクル比 $\left(=c_{j}{ }^{\prime}+c_{j}\right)$ を用いて疲労損傷の評価を与兄ている。因 に,

$$
\begin{gathered}
c_{j}{ }^{\prime}=\left(\cdots \cdots\left(\left(c_{1}\right)^{m_{1} / m_{2}}+c_{2}\right)^{m_{2} / m_{3}}\right. \\
\left.+\cdots \cdots c_{j-1}\right)^{m_{j-1} / m_{j}}
\end{gathered}
$$

\section{3 疲労限以下の負荷サイクルに対す る評価}

いま全く疲労損傷を受けていないときの 基本疲労強度曲線を次式のように Stromeyer 式で表示する。

$$
N=A_{1} \cdot\left(\varepsilon-\varepsilon_{e 0}\right)-K_{1}
$$

ここに $A_{1}$ および $\varepsilon_{e 0}$ は定数。 $\varepsilon_{e 0}$ を超え る振幅により疲労損傷が与えられ, その損 傷量 $D$ に応じて $\varepsilon_{e 0}$ が低下すると考えると， (23)式中の仮想疲労限 $\varepsilon_{e 0}$ を非損傷材の疲 労限に対応させ，Dだけ損傷を受けた後の 疲労限を $\varepsilon_{e D}$ と表わすことができる。本研 究では, $\varepsilon_{e D}$ と $\varepsilon_{e 0}$ の関係を Haibach 流 ${ }^{1)}$ に次式のように仮定した。

$$
\varepsilon_{e D}=\varepsilon_{e 0}(1-D)^{1 / \gamma p}
$$

ここに $\gamma_{p}$ はブロック形状を表わすパラメ 一タ $p$ と $\bar{S}_{a}$ との関数で次式で与えられ る。

$$
\gamma_{p}=\sum_{j=1}^{8} c_{j}
$$

よってある損傷量 $D$ によって疲労限が低下した際の基本 疲労強度曲線は (23)式中の $\varepsilon_{e 0}$ を $\varepsilon_{e D}$ に置き換えて表 わされる。

$$
N=A_{1} \cdot\left(\varepsilon-\varepsilon_{e D}\right)^{-K_{1}}
$$

(26)式の瘦労強度曲線は Fig. 3 のように, 損傷 $D$ によ って変化する。

結局, 疲労のごく初期は $\varepsilon_{e 0}$ を超える振幅によって損 傷が与えられることにより $\varepsilon_{e 0}$ が逐次低下し始め, それ までに与兄られた損傷量 $D$ に応じて $\varepsilon_{e D}$ は低下する。例 えば図中 $D=0.8$ の曲線と $\varepsilon_{e D}(0.8)$ はそれまでに与え られた $D=0.8$ の損傷量によって $D=0$ の $\varepsilon-N$ 線図 と $\varepsilon_{e_{0}}$ が仮想的にそこまで低下したことを意味し，換言 すれば残存寿命の予測に当ってはこの線を基準としてサ イクル比や残存許容損傷量を計算する。同図は $\gamma_{p}=1$ の場合を例示しているが (式 (24)), $\gamma_{p} \gtrless 1$ に対応する 仮想的な $\varepsilon-N$ 曲線は特に高サイクル側で上下する。

一方，基本疲労強度曲線が 2 直線で表示される場合に は, Fig. 4 に示すようにまず基本線図は次式で与えら れ，そして非損傷材疲労限 $S_{e 0}$ が存在すると考える。

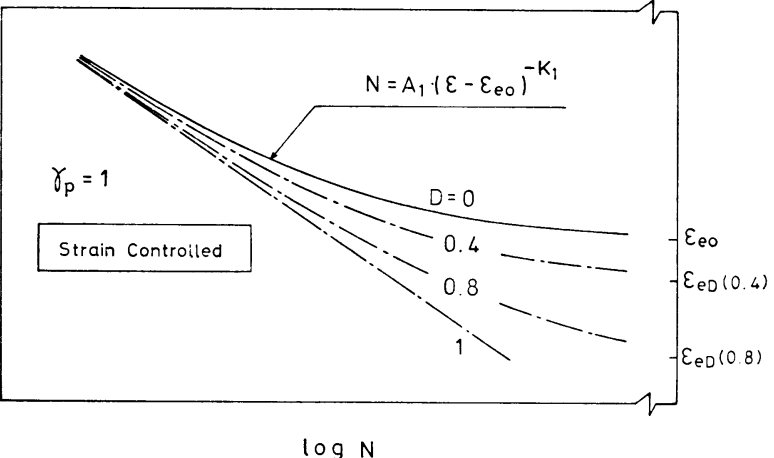

Fig. $3 \varepsilon-N$ curves for undamaged $(D=0)$ and damaged conditions (Stromeyer's expression)

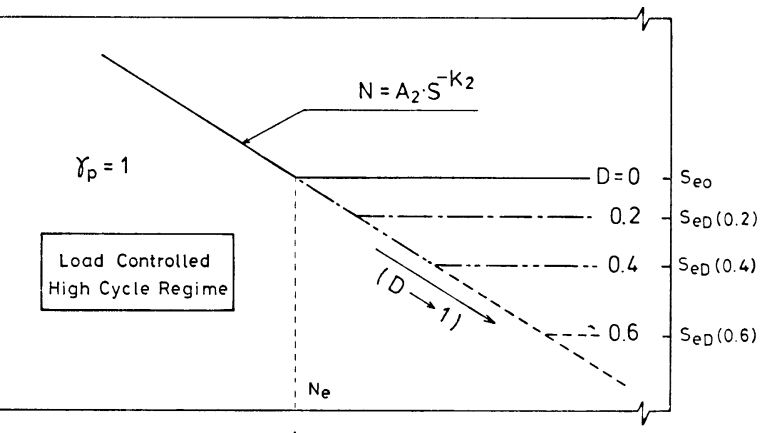

$\log N$

ig. $4 S-N$ curves for undamaged $(D=0)$ and damaged conditions (Bi-linear expression)

$$
N=A_{2} \cdot S^{-K_{2}}
$$

Fig. 3 についての考方方に従って非損傷材の疲学限 $S_{e 0}$, 損傷材の疲労限 $S_{e D}$ を(24) 式の $\varepsilon_{e 0}, \varepsilon_{e D}$ に対応させ ると

$$
S_{e D}=S_{e 0}(1-D)^{1 / \gamma p}
$$

が得られ，Stromeyer式に対する取扱いと同様に，任意 の疲労過程においてある損傷 $D$ を受けた後の疲労限 $S_{e D}$ を超觉るような応力ステップのみが損傷を与えると考え る。損傷に伴う基本 $S-N$ 曲線の变化（疲労限の低下） の例を図に示す。本図の場合は, 例えば $D=0.6$ までの 損傷を受けた際の残存許容損傷量の計算に当っては， $D$ $\rightarrow 1$ と傍記したオリジナルの $S-N$ 線図を $D=0.6$ で示 される水平線に結合した 2 直線近似の線図が基本 $S-N$ 曲線となる。

以上のような評価汇從って子測疲労寿命は，(17）, (20)，(21)，(24)，(26）式などから算出されるが，その 寿命予測手順を Fig. 5 に示す。

\section{3 解析対象デー夕}

解析対象としたデータは原子炉圧力容器用 SFVV 3

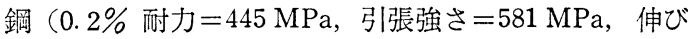




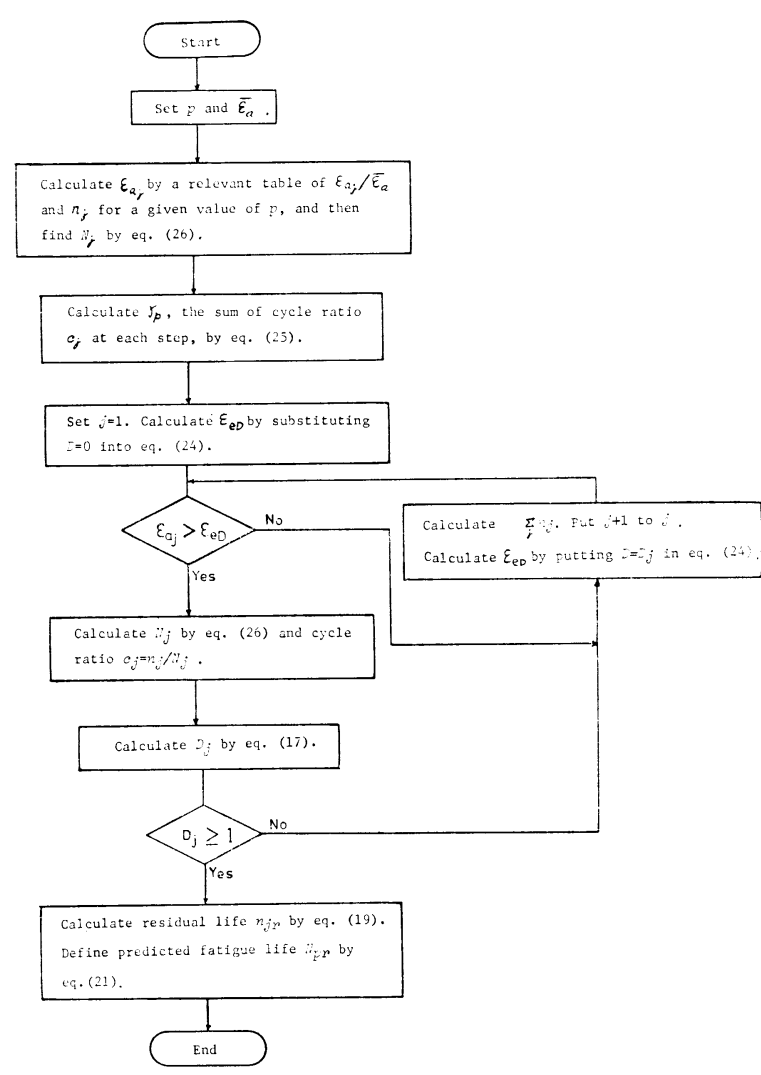

Fig. 5 Flow chart for calculation of predicted fatigue life in block loading with $p$ distribution

$=30.9 \%$, 絞り百分率 $=75.3 \%$ ), 乾鋼 SM $41 \mathrm{~A}$ ならび 飞 $500 \mathrm{MPa}$ 級高張力鋼 SM $50 \mathrm{~B}$ の 3 鋼種を母材とす る試嵞片を用いて行われた分布ブロック形状による疲 労試験データである。な拉 SM $41 \mathrm{~A}$ 鋼汇ついては前々 報 ${ }^{2} ， \mathrm{SM} 50$ B 鋼については前報 ${ }^{3}$ 亿，母材の機械的性 質, 試験片形状拉よび試騟データその他について述べて 岕る。一方, SFVV 3 鋼记関する試験方 法やデータの詳細は文献 9）に詳述して 岁るので，ここではその概略を述べるに とどめる。

SFVV 3 鋼总母材とした疲労試験は 2 種類の試験片を用いて行われた。 ASTME 606-77 T に準じた平行部付平 滑丸棒試験片 $(10 \mathrm{~mm}$ 径, $\mathrm{GL}=12 \sim 20$ $\mathrm{mm}$ ）は，主として歪速度が $0.1 \sim 2.52$ \%/sec の三角波に上る軸方向歪制御試験 て用いられた。なお，同試験片を用いて 荷重制御で試験されたデータもある。一 方, ASTM E 466-76 T に準じた砂時計 型丸棒試験片 (30 mm 径)はすべて繰返
Table 1 Block loading shape for SFVV 3 steel specimens

\begin{tabular}{|c|c|c|c|c|c|c|}
\hline \multirow{2}{*}{$\begin{array}{c}\text { Step } \\
\text { No. } \\
i\end{array}$} & \multicolumn{4}{|c|}{$\varepsilon_{a} / \bar{\varepsilon}_{a}$} & \multicolumn{2}{|c|}{$\begin{array}{l}\text { Strain Cycles } \\
\text { Imposed }\end{array}$} \\
\hline & $p=1$ & $p=0$ & $p=0.5$ & $p=$ & $n_{i}$ & $\sum n_{i}$ \\
\hline 1 & 1 & 1 & 1 & 1 & 1 & 1 \\
\hline 2 & 1 & 0.988 & 0.975 & 0.963 & 1 & 2 \\
\hline 3 & 1 & 0.963 & 0.925 & 0.888 & 3 & 5 \\
\hline 4 & 1 & 0.932 & 0.863 & 0.794 & 27 & 32 \\
\hline 5 & 1 & 0.895 & 0.788 & 0.682 & 200 & 232 \\
\hline 6 & 1 & 0.857 & 0.713 & 0.568 & 918 & 1,150 \\
\hline 7 & 1 & 0.820 & 0.638 & 0.456 & 2,800 & 3,950 \\
\hline 8 & 1 & 0.782 & 0.563 & 0.344 & 6,050 & 10,000 \\
\hline
\end{tabular}

し速度 135 1 $140 \mathrm{~Hz}$ の正弦波による軸方向荷重制 御試験に用いられた。なお歪制御および荷重制御試 験とも，室温大気中， $R=-1$ の試験条件で行われた。 同試験に用いた $p$ 分布ブロック波形は同試験が低 サイクル領域を含めて行われたため，2節で示した ブロック波形を，1ブロックの大きさが $10^{6}$ サイク ルから $10^{4}$ サイクルとなるように修正された。荷重 負荷順序は荷重濑減型，つまり第1 ステップから始 まり $2 \rightarrow 3 \cdots \cdots \rightarrow 7 \rightarrow 8$ といら順序で負荷し，その 後再び第 1 ステップに戻って同様な負荷を試験片が 破断する（定常状態の $75 \%$ まで上限荷重が低下し たときの寿命) まで繰返すという方法である。p分 布ブロック荷重試験は， $p=0.25 ， 0.5 ， 0.75$ の 3 つのシリーズについて行われたが，各ステップの歪 振幅比之繰返し数の関係を Table 1 に示す。

解析データ中, 寿命推定の基礎となる $p=1$ のデータ つまり定歪振幅疲学試験データおよび Stromeyer 式に よる最適曲線を Fig. 6 の丸と三角印ならびに実線で示 す。なお○は歪制御, $\triangle$ は荷重制御試験によるデータで ある。また同曲線は Stromeyer 式の定数項, すなわち

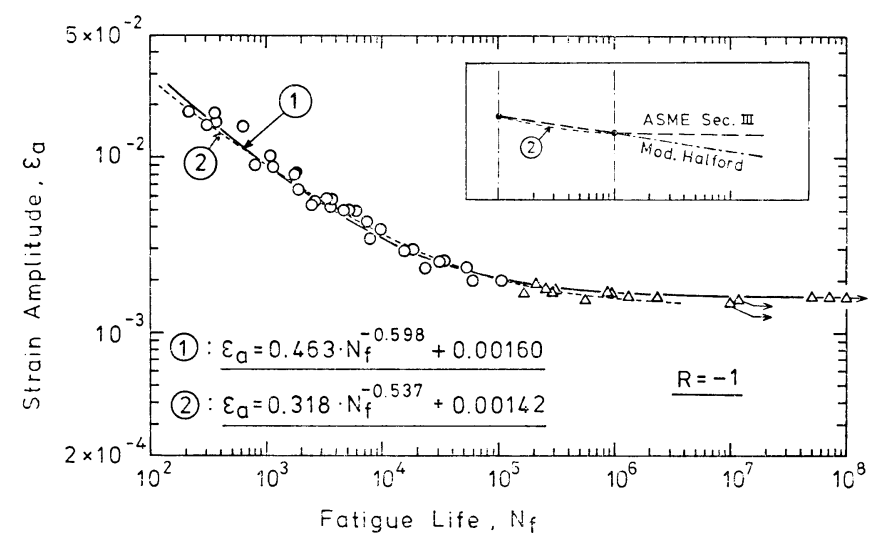

Fig. 6 Basic $\varepsilon-N$ curves fitted to experimental fatigue lives for SFVV 3 steel specimens 
仍想的な瘦労限に相当する項に，10 $10^{3}$ サイクルにおける 瘦労強度 $\left(\varepsilon_{a}=0.16 \%\right)$ を当てはめ, 回帰することによ って次式のように得られたものである（Fig. 6 の曲線 (1) $\%$

$$
\varepsilon_{a}=0.463 \cdot N_{f}^{-0.598}+0.0016
$$

なお，亀裂発生寿命 $N_{c}$ と破断寿命 $N_{f}$ との間には $p$ の值にかかわらず,

$$
N_{c}=0.50 \cdot N_{f}^{1.05}
$$

といら関係が得られており, 各頻度分布のデータに対す る寿命推定精度については，両者のどちらを基準にとっ ても大差がなく傾向も変わらないため, SFVV 3 鋸につ いては $N_{f}$ を基準に寿命予測を行らことにする。

\section{4 解析データに対する提案モデルの適用 と従来の各方法との比較}

\subsection{Stromeyer 表示式に基づく寿命予測}

第 2 節に提案したモデルのうら低・高サイクル寿命域 疲労線図の表示式としての Stromeyer 式に基づくモデ ルを SFVV 3 鋼の $p$ 分布ブロック疲労試験結果に適用 して，本モデルによる推定寿命 $N_{p r}$ と実験により得ら れた寿命 $N_{\exp }$ との相関を検討した結果 Fig. 7 を得た。 併せて Miner 法による $N_{p r}$ と $N_{\exp }$ との関俰も同困 に示してある。実験値と Miner の方法による推定寿命 は，低寿命側では比較的良く一致しているが，長寿命偩 特に疲労限以下のステップを含むようなデータ（図中の プライム記号付データ）については極端に非安全側に位 置している。それに比べて今回提案した同こデルによる 推定寿命と実験值との比は長寿命側で若干小さな（安全 過ざる)值となっているが， $N_{\text {exp }} \fallingdotseq 3 \times 10^{5}$ の点を除いて 約 1/万〜2の範囲に収まって拈り, Minerの方法による 長寿命側での非安全性が改善されていることがわかる。

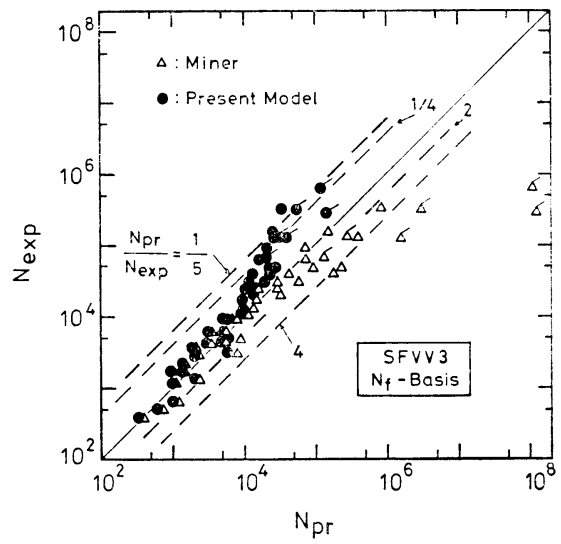

Fig. 7 Relations between predicted and experimental fatigue lives for SFVV 3 steel (right prime data refer to $\varepsilon_{a \imath}<\varepsilon_{\varepsilon^{\circ} \mathrm{O}}, i$ is arbitrary number from 1 to 8 )
4. 2 ASME Sec. III 流の疲学綄図に基づく寿命予測 原子炉圧力容器の構造強度に㧍いて, 現在広く使用さ れている規格は, ASME の Boiler and Pressure Vessel Code, Sec. III であり，わが国の規格も基本的には これに準じている。同規格における疲学設計の基礎とな る疲労強度線図は，10 から $10^{6}$ の寿命範囲について与 えられており，10サイクル以下の領域については疲労解

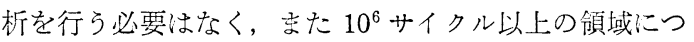

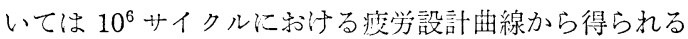
疲労強度をいわば疲労限と考兄ている。一方, 糸積疲学 被害の評俩は単純な Miner の方法によることにしてあ る。

ASME Sec. III の疲学設計手法がひとり原子力のみな らず他分野においても, 若干変形を加えられたらえで用 いられている現状にかんがみ，10〜106 サイクルの範囲 内のデータしか得られていないと想定して, ASME Sec. III流の解析を試みてみる。

まず Fig. 6 について $10^{6}$ サイクルまでのデータを用 いて，再び Stromeyer 式を適用すると次式が得られる。

$$
\varepsilon_{a}=0.318 \cdot N_{f}^{-0.537}+0.00142
$$

（31）式による曲線は Fig. 6 の破線（2) で示される。 なお $10^{6}$ サイクルにおける疲労強度をそのまま水平に長 寿命側へ延長するのが, 累積疲労被害評価に際しての ASME Sec. III の方法で市る。

一方, $10^{5}$ および $10^{6}$ サイクルにお汁る疲学強度を結 ぶ值線の傾きに基づいて $10^{6}$ サイクル以上の領域での外 挿曲線を決定方る Halford ${ }^{8)}$ の考克に良って，それを若 干修正し，106 サイクル以上の領域について同傾斜を持 つ直線で延長したものが図中の 1 点鎖線である。この延 長線に基ついて累積被害評洒をする方法はいわば修正

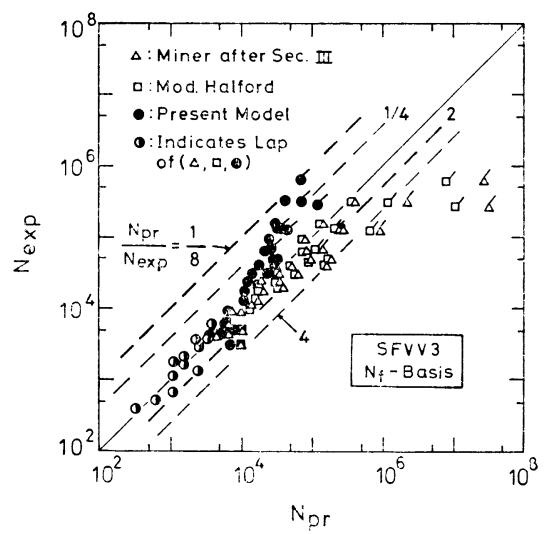

Fig. 8 Relations between predicted and experimental fatigue lives for SFVV 3 steel (based on $\varepsilon-N$ diagram for cycle range of 10 to $10^{6}$ cycles, right prime data refer to $\varepsilon_{a \imath}<\varepsilon_{e o}, i$ is arbitrary number from 1 to 8 ) 
Miler 法に該当するであるう。Fig. 8 に, ASME Sec. 世流の方法に上る基本 $\varepsilon-N$ 曲線を朋いて求的た推定寿 命 (Fig. 8 に秥活る Miner after Sec. III), Halford 流 の外插に上る基本 $\varepsilon-N$ 曲線に従って得られた推定寿命 (Mod. Haliord)，そして（31）式に基づいて本モデルを 適用して求的九推定寿命 (Present Model) を比較し た。同図からわかるように, ASME Sec. III に従って求 めた推定寿命江寿命全般について最も危除側位置して おり，その程度は疲労限以下のステップを含むよらな長 寿命例で著しい(プライム付データ参照)。また Halford 流の外㨂法沉る推定檤は, ASME Sec. III によるもの と比べ長寿命側での非安全性が若干改善されてはいるも のの寿命全船沉たりなお非安全推定となっている。以 上2つの手法による推定寿命に比べ, 本諭文で提案した モデルによる寿命推定は, 前二者による非安全推定をか なり改善しており，安全側に片寄りすぎている嫌いの出 るデータも㟧るが，本モデルによる奉命推定は良好之い 兑よう。

\subsection{2 直線表示式に基づく寿命予測}

以前, 著者の一人は SM $41 \mathrm{~A}$ 鋼を用いて荷重制御に よるか分布ブロック荷重試験を行った2\%。同試験データ に本モデルを適用した結果を Miner そして Haibach の方法による推定寿命と併せて Fig. 9 亿示す。同図から わかるように Miner の方法による寿命推定は長寿命側 特に疲労限以下のステップを含むよらなデータ（プライ ム記号のついてないデータ）に対し非安全となってお り, また Haibach の方法によると非安全推定が若干改 善さ礼ているが，同法による寿命推定はまだ良好とはい いがたい。本モデルによる推定寿命はこの点でさらに改 善されて抢り, 若千安全側過ぎる推定となっている 2 点 $\left(N_{\mathrm{exp}}=1 \times 10^{7}, 1.15 \times 10^{7}\right)$ を除けば良好な寿命推定を 与克ている。

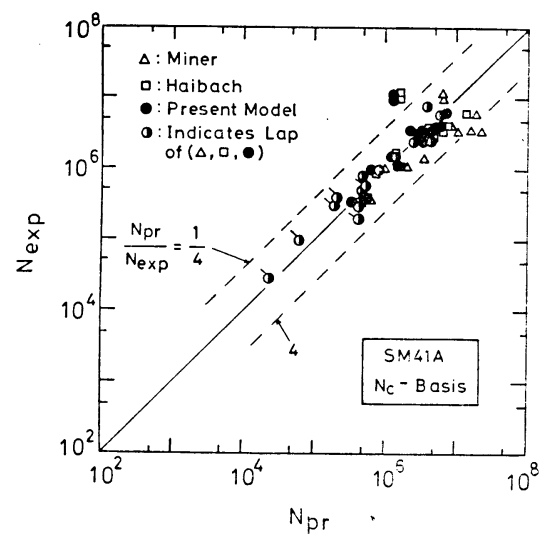

Fig. 9 Relations between predicted and experimental fatigue lives for SM $41 \mathrm{~A}$ steel (left prime data refer to $S_{a \ell}>S_{e 0}, i$ is 1 to 8 )

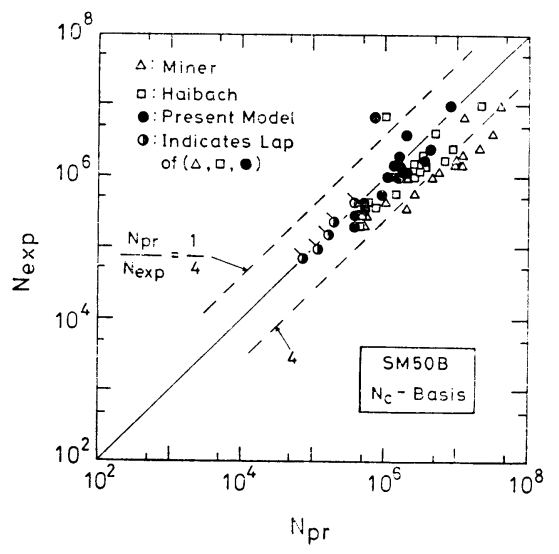

Fig. 10 Relations between predicted and experimental fatigue lives for SM $50 \mathrm{~B}$ steel (left prime data refer to $S_{a i}>S_{e 0}, i$ is 1 to 8 )

次に同様な比較を, 前報の試験結果 ${ }^{3)}$ つまり SM 50 B 鋼について行っ忠ものが Fig. 10 である。SM $41 \mathrm{~A}$ 鋼に 対する推定と同㥞 Miner の方法による推定寿命は $10^{5}$ サイクル近傍のデータを除いて, すべて非安全側に位置 し, Haibachの方法で若干改善されてはいるもののなお 不充分である。これら 2 つ推定方法に比べ, 本モデル による寿命推定により試験データ全般の非安全推定が改 善され, 極端に安全侧位置している $N_{\exp }=6.81 \times 10^{5}$ の点を除いて，本モデルは良好な寿命推定を与兄てい る。

以上のようにして, 本モデルを $\mathrm{SFVV} 3$ 鋼, SM $41 \mathrm{~A}$ 鋼拈よび SM 50 B 鋼の 3 鋼種について 適用した結果, 鋼種の湋いにかかわらず良好な寿命推定が得られた。

なお，前述のように本論文では（7）式の指数を 0.3 としたが, この值はなお今後のデータ蓄積によって若干 変わる值で台るかも知れない。参考のためこの指数を仮 に 0.5 とした場合, Fig. 7，8，9，10 にお汁る Present Model の点がどのように移動するかを調べてみた。そ の結果, 安全推定側之非安全推定側の極値を通る $N_{p r} /$ $N_{\exp }$ の比は, 指数を 0.3 から 0.5 に変学ることによ りそれぞれ，Fig. 7 では大略 1/5 から大略 1/4 出よび 大略 2 から大略 4 へ, Fig. 8 では $1 / 8$ から 1/4 および 2 から 3 へと変化したが, Fig. 9 および Fig. 10 では縦 横軸値の関釈位置はほとんど変化しなかった。したがっ て本論文ではむしろ $N_{p r} / N_{\exp }$ の分散が 安全推定側に かたよっている方が望ましいとの立場をとって（7）式 の指数は, 0.3 のままとした。

\section{5 結論}

（1）疲労損傷をサイクル比の $m$ 乗で評洒した前報の モデルを発展させ, 指数 $m$ を遷移歪振幅まなは降伏応力 
ならびに歪振幅または応力振幅の関数とし, さらに荷重 負荷順序拉よび各ステップの大きさを考慮した変換サイ クル比で疲労損傷を評価した。そして疲労損傷によって 低下寸る疲労限を逐次基本疲労寿命式汇取り入れ, 疲労 寿命を推定するモデルを提案した。

同モデルは 2 直線表示のみならず Stromeyer 表示に よる広域疲労寿命線図湳用でき，同モデルにより解析 対象データとした SFVV 3 鋼, SM $41 \mathrm{~A}$ 鋼ならびに SM 50 B 鋼の 3 鋼種に対する良好な疲労寿命推定が示さ れた。

（2）基本 Stromeyer 曲線を ASME Sec. III の手 法にならって, $10^{6}$ サイクル以上の高サイクル領域へ水 平外挿する方法は, 高サイクル域特に疲労限以下の歪ス テップを含むデータに対し非安全な寿命推定を与兄る。 また, $10^{5} \sim 10^{6}$ サイクルの疲学寿命曲線の傾きを用いて 同領域への外插を行ら修正 Halford の方法法, ASME Sec. III 流の方法に比べその非安全推定を若干改善して はいるものの, 安全側の推定はな称不充分である。

この両者に対し， $10^{6}$ までのデータに基づいて得られ た Stromeyer 曲線を, 本論文で提案した方法によって 外插し，本モデルを適用した結果良好な推定寿命が得ら れた。

\section{謝辞}

本研究はてとり著者らが得たデータのみならず, FRC -79, FRC-80 委員会において実験を分担された研究者 らによって得られたデータを含めて行ったもので, ここ に, こ机らのデータを出され，また同データの引用を快 諾して下さった委員の方々に謝意を表する次第である。

\section{参考文 献}

1) E. Haibach : Modifizierte Lineare Schadensakumulations-Hypothese zur Berücksichtigung des Dauerfestigkeitsabfalls mit Fortschreitender Schädigung, LBF, Darmstadt, Tech., Mitt., Nr. 50 70 (1970).

2）飯田國廣，金子昭久：p分布ブロック荷重による 累積疲労被害の一検討, 日本造船学会論文集, 第 144 号 (1975), 381/389.

3）飯田國廣, 洪 性㻈：p分布荷重儿上る累積疲労 被害 (第一報), 日本造船学会諭文集, 第 148 号 (1980), 268/273.

4) S. M. Marco and W. L. Starkey : A Concept of Fatigue Damage, Trans. of ASME, 76(1954), $627 / 632$.

5) Z. Hashin and A. Rotem: A Cumulative Damage Theory of Fatigue Failure, Materials and Engineering, 34 (1978), 147/160.

6) S.S. Manson and G. R. Halford : Practical Implementation of the Double Linear Damage Rule and Damage Curve Approach for Treating Cumulative Fatigue Damage, Int. Journ. of Fracture, 17 (1981), 169/192.

7）飯田國䐵, 小沢継太郎, 永井英睛, 洪 性㻈: 歪 制御低サイクル疲労に打けるヒステリシスループ の解析之寿命推定, 日本造船学会論文集, 第 150 号 (1981), 471/481.

8) G. R. Halford: A Recomended Procedure for Extrapolating Fatigue Curves beyond One Million Cycles to Failure, Prepared for The Working Group on Creep-Fatigue, NASALewis Research Center (1978).

9）滰子炉構造物の強度安全性評価法の合理化汇関 する研究, 日本溶接協会報告, JWES-AE-8103 (1981) 斿よび JWES-AE-8204 (1982). 